\title{
Regulation of Hepcidin-25 by Short- and Long-Acting rhEPO May Be Dependent on Ferritin and Predict the Response to rhEPO in Hemodialysis Patients
}

\author{
Kazuya Takasawa ${ }^{a}$ Naohisa Tomosugic Chikako Takaedaa \\ Teiryo Maeda ${ }^{d}$ Norishi Uedab \\ ${ }^{a}$ Division of Nephrology, Department of Internal Medicine, and bepartment of Pediatrics, \\ Public Central Hospital of Matto Ishikawa, and ' $D$ Division of Advanced Medicine, Medical \\ Research Institute, Kanazawa Medical University, Ishikawa, and dBiomarker Society, \\ Kawasaki, Japan
}

Key Words

Anemia · Erythropoietin · Ferritin · Hemodialysis · Hepcidin · Iron deficiency

\section{Abstract}

Background/Aims: We examined whether regulation of hepcidin-25 by short- or long-acting recombinant human erythropoietin (rhEPO) is dependent on ferritin and predicts the response to rhEPO in hemodialysis (HD) patients. Methods: Two studies with rhEPO were performed in $9 \mathrm{HD}$ patients with a 2-year interval. Serum hepcidin-25 was measured at 0-18 h after intravenous epoetin- $\beta$ (EPO) or methoxy polyethylene glycol-epoetin- $\beta$ (PEG-EPO) administration and on days 3-7 after PEG-EPO. Hemoglobin $(\mathrm{Hb})$, serum ferritin, transferrin, $\mathrm{C}$ reactive protein (CRP), and interleukin (IL)- 6 were analyzed before hepcidin measurement and 6 months after rhEPO. Based on the serum ferritin levels before hepcidin measurement, the patients in the two studies with EPO or PEG-EPO were combined into low (11; serum ferritin of $<15.0 \mathrm{ng} / \mathrm{ml}$ ) and high ferritin groups (7; serum ferritin of $\geq 15.0 \mathrm{ng} / \mathrm{ml}$ ). The response of hepcidin-25 to rhEPO and the effect of rhEPO on anemia were compared between the groups. Results: The serum hepcidin-25 levels rose at 6-9 h and returned to the baseline at $18 \mathrm{~h}$ after EPO. They rose at $6-9 \mathrm{~h}$, returned to the baseline at $18 \mathrm{~h}$, and decreased on day 5-7 after PEGEPO. Serum hepcidin-25 levels were low $(<5.0 \mathrm{ng} / \mathrm{ml})$ in the low ferritin group, but rose at 6-9 h after rhEPO in the high ferritin group. Serum transferrin levels were similar, and CRP and IL- 6 were normal in both groups. Hb tended to increase in the low ferritin group, but it significantly decreased in the high ferritin group after rhEPO. Conclusion: Regulation of hepcidin- 25 by rhEPO may be dependent on ferritin, affecting the response to rhEPO in HD patients. 
Takasawa et al.: Regulation of Hepcidin- 25 by Short- and Long-Acting rhEPO May Be Dependent on Ferritin and Predict the Response to rhEPO in Hemodialysis Patients

\section{Introduction}

Iron deficiency anemia is an important problem commonly associated with patients on maintenance hemodialysis (HD). Hepcidin-25, the major form of mature hepcidin, plays an important role in the regulation of iron metabolism $[1,2]$. Binding of hepcidin to its receptor ferroportin (FPN) is the principal cellular process for iron efflux, which, in turn, causes the rapid internalization and degradation of FPN $[1,2]$. In duodenal enterocytes, high hepcidin prevents the movement of dietary iron into the circulation through its binding to FPN. In hepatocytes or macrophages, hepcidin prevents the efflux of stored iron into the circulation. Conversely, low hepcidin increases intestinal iron absorption and iron efflux from macrophages or hepatocytes $[1,2]$.

Hepcidin-25 is synthesized in the liver in response to iron overload or inflammation [1, 2]. Excess hepcidin decreases iron availability for erythropoiesis, leading to its inhibition. As described in our previous study [3], serum levels of hepcidin and ferritin have been usually increased in HD patients [4-6], and hepcidin levels were correlated positively with ferritin and negatively with erythrocyte count, hemoglobin $(\mathrm{Hb})$ and hematocrit $[3,4,6]$. Similarly, serum levels of prohepcidin, a prohormone of hepcidin, were correlated negatively with $\mathrm{Hb}$ in HD patients [7]. In iron depletion, reflected by low serum ferritin, serum levels of hepcidin- 25 were decreased, facilitating iron availability for erythropoiesis in HD patients [8]. Intravenous iron administration has been shown to increase serum levels of hepcidin in HD patients [9]. These data suggest that hepcidin levels are regulated by the iron storage status.

The long-term administration of recombinant human erythropoietin (rhEPO) affects serum levels of hepcidin or prohepcidin in HD patients [5, 10-13]. Regarding the early effect of rhEPO on hepcidin, there are a few studies using healthy volunteers showing an early and significant rise [14, 15] followed by suppression of hepcidin [14-16] after intravenous or subcutaneous administration of rhEPO. So far, there is no study on the early effect of rhEPO administration on serum hepcidin-25 in HD patients. In addition, it is unknown whether the regulation of hepcidin- 25 by short- and long-acting rhEPO is different, and whether rhEPOinduced regulation of hepcidin-25 is dependent on ferritin in HD patients. Furthermore, it remains inconclusive whether an alteration of serum hepcidin- 25 is predictive of the response to rhEPO in HD patients [5, 10-13]. The present study was undertaken to address these issues in HD patients.

\section{Subjects and Methods}

The Institutional Review Board at our institution approved this study. Informed consent was obtained from all patients. Nine patients on maintenance HD without diabetes mellitus, hepatic disease, or clinical infection were enrolled in the study. To minimize intraindividual variability of serum hepcidin $[17,18]$ and the effect of dialysis on hepcidin [11], two independent studies for the response of hepcidin- 25 to the short-acting epoetin- $\beta$ (EPO) and the long-acting methoxy polyethylene glycol-epoetin- $\beta$ (PEG-EPO) were performed using the same patients and dialysis condition with a 2-year interval.

To examine the early response of hepcidin- 25 to the short- or long-acting rhEPO, serum levels of hepcidin-25 were measured at $0,3,6,9$ and $18 \mathrm{~h}$ after intravenous administration of EPO (3,000 U) or PEG-EPO (100 U). In addition, they were measured on days 3, 5, and 7 after administration of PEG-EPO. During this study, PEG-EPO was witheld for 7 days until the measurement of hepcidin-25 was completed. In two independent studies with EPO or PEG-EPO, all patients received the constant dose of the same agent of rhEPO for 6 months before, during, and 6 months after the measurement of hepcidin. As rhEPO therapy, EPO 
Table 1. Clinical parameters before the measurement of hepcidin-25 in response to the short- or long-acting rhEPO in HD patients
Takasawa et al.: Regulation of Hepcidin- 25 by Short- and Long-Acting rhEPO May Be Dependent on Ferritin and Predict the Response to rhEPO in Hemodialysis Patients

\begin{tabular}{lcc}
\hline Variable & $\begin{array}{l}\text { Before EPO } \\
(\mathrm{n}=9)\end{array}$ & $\begin{array}{l}\text { Before PEG-EPO } \\
(\mathrm{n}=9)\end{array}$ \\
\hline $\mathrm{Hb}, \mathrm{g} / \mathrm{dl}$ & $10.3 \pm 1.4$ & $11.1 \pm 2.7$ \\
Ferritin, $\mathrm{ng} / \mathrm{ml}$ & $38.2 \pm 50.7$ & $15.3 \pm 11.1$ \\
Transferrin, $\mathrm{mg} / \mathrm{dl}$ & $254.8 \pm 47.7$ & $265.7 \pm 36.8$ \\
$\mathrm{CRP}, \mathrm{mg} / \mathrm{ml}$ & $0.05 \pm 0.07$ & $0.1 \pm 0.17$ \\
$\mathrm{IL}-6, \mathrm{pg} / \mathrm{ml}$ & $2.3 \pm 1.2$ & $4.3 \pm 3.1$ \\
\hline
\end{tabular}

(750-3,000 U) and PEG-EPO (100-150 U) were intravenously given 3 times a week and once a month, respectively.

Based on the baseline levels of serum ferritin before the measurement of hepcidin, the patients were divided into low (serum ferritin of $<15.0 \mathrm{ng} / \mathrm{ml}$ ) [19] and high ferritin groups (serum ferritin of $\geq 15.0 \mathrm{ng} / \mathrm{ml}$ ). The patients with low or high levels of serum ferritin in two independent studies were combined and grouped into low or high ferritin groups, respectively. An alteration of serum hepcidin-25 after intravenous administration of rhEPO was compared between the groups. To determine whether an alteration of serum hepcidin- 25 and ferritin is predictive of the effect of rhEPO therapy on anemia, $\mathrm{Hb}$ and iron parameters, including serum ferritin and transferrin, before and 6 months after the measurement of hepcidin were compared between the groups. In addition, to examine the influence of inflammation on serum hepcidin-25, serum levels of interleukin (IL)-6 and C-reactive protein (CRP) were compared between the groups. All parameters analysed were measured just before starting HD. In our series, ultrapure dialysate has been used for HD to minimize microinflammation as previously described [6].

Serum levels of hepcidin-25 were measured using a liquid chromatography-tandem mass spectrometric method as previously described [20]. Hb, serum ferritin, transferrin, and CRP were measured by the standard automated laboratory methods, and serum IL-6 by an enzyme-linked immunosorbent assay.

\section{Statistical Analysis}

Continuous data are expressed as mean \pm SD and categorical data as percentage of the total population. Comparisons of two means were performed using the Mann-Whitney U test, and those of two proportions using the Fisher exact test. A software package (SPSS, version 20.0; SPSS Inc., Chicago, Ill., USA) was used for statistical analysis. A p value $<0.05$ was considered significant.

\section{Results}

In 9 patients ( 4 males) on maintenance HD, mean age at the time of the study and duration of HD were $59.0 \pm 7.0$ years and $120.0 \pm 95.0$ months, respectively. Table 1 shows the clinical parameters of the HD patients before the measurement of hepcidin after administration of rhEPO in two independent studies. There was no significant difference in $\mathrm{Hb}$, serum levels of ferritin, transferrin, CRP, and IL-6 values before the measurement of hepcidin between the studies.

Serum levels of hepcidin-25 rose from the baseline of $6.8 \pm 9.8$ to $15.9 \pm 20.9 \mathrm{ng} / \mathrm{ml}(\mathrm{p}<$ $0.05)$ at $6 \mathrm{~h}$, then declined to $13.8 \pm 18.0 \mathrm{ng} / \mathrm{ml}(\mathrm{p}<0.05)$ at $9 \mathrm{~h}$, and returned to the baseline

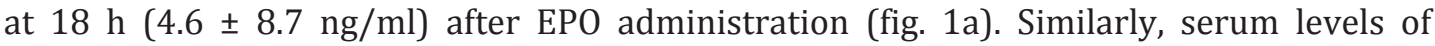
hepcidin- 25 rose from the baseline of $10.9 \pm 13.6$ to $25.0 \pm 29.3 \mathrm{ng} / \mathrm{ml}(\mathrm{p}<0.01)$ at $6 \mathrm{~h}$, then 

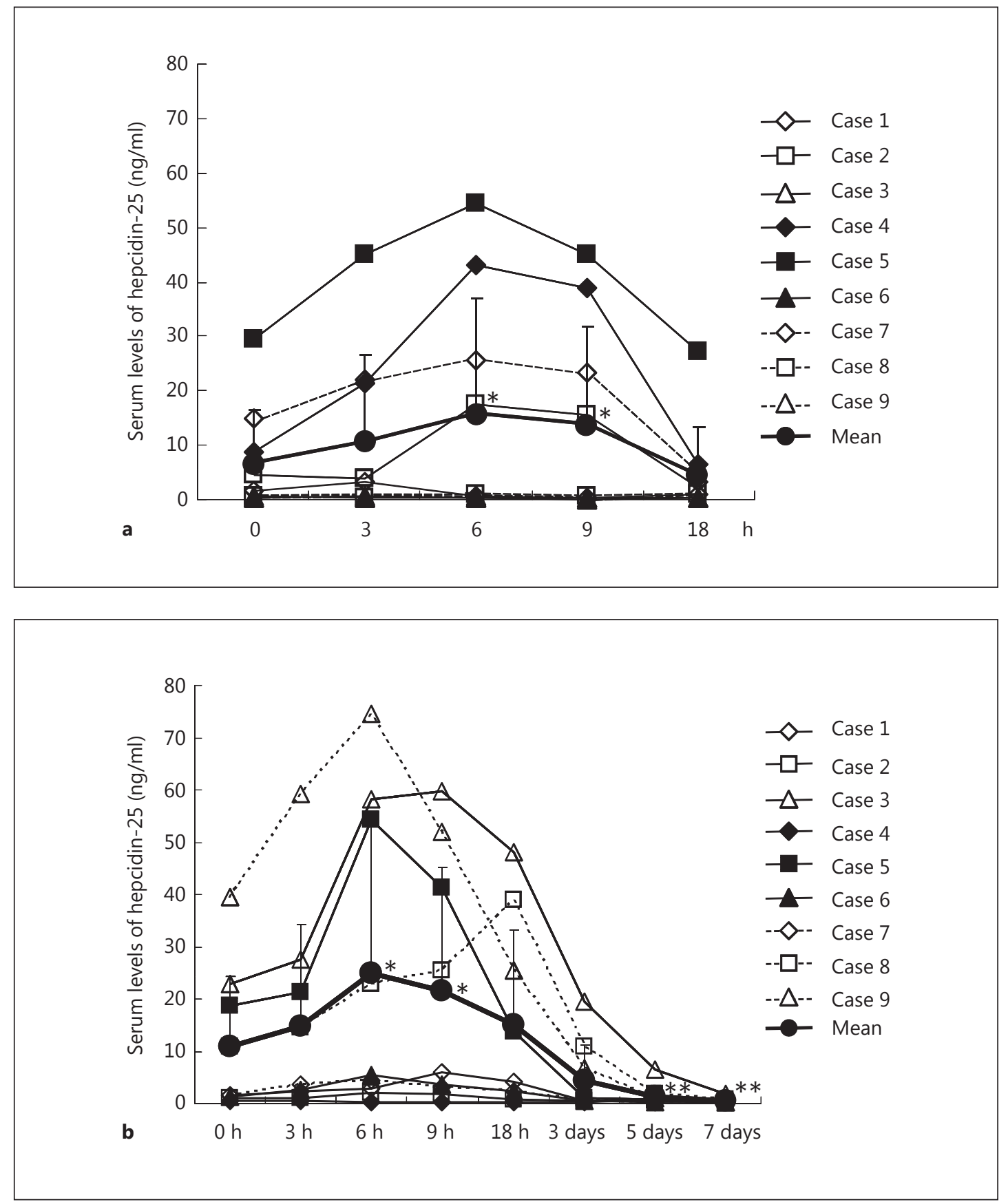

Fig. 1. Alteration of serum levels of hepcidin-25 in response to the intravenous administration of EPO (a) and PEG-EPO (b) in patients on maintenance HD. a * p $<0.05,0$ vs. 6 and 9 h. b * p $<0.01,0$ vs. 6 and 9 h, ${ }^{* *}$ p $<$ $0.05,0$ h vs. day 5 and day 7 .

declined to $21.5 \pm 23.8 \mathrm{ng} / \mathrm{ml}(\mathrm{p}<0.01)$ at $9 \mathrm{~h}$, and returned to the baseline at $18 \mathrm{~h}(15.2 \pm$ $18.1 \mathrm{ng} / \mathrm{ml}$ ) after PEG-EPO administration (fig. 1b). Serum levels of hepcidin-25 on day 3 $(4.5 \pm 6.7 \mathrm{ng} / \mathrm{ml})$ tended to be decreased, but did not differ significantly from the baseline. However, they were significantly decreased on day $5(1.4 \pm 1.9 \mathrm{ng} / \mathrm{ml}, \mathrm{p}<0.05)$ and day 7 $(0.5 \pm 0.4 \mathrm{ng} / \mathrm{ml}, \mathrm{p}<0.05)$ after PEG-EPO administration, compared to the baseline. 
Table 2. Dose of rhEPO and serum levels of ferritin before the measurement of hepcidin-25

\begin{tabular}{|c|c|c|c|c|}
\hline \multirow[t]{2}{*}{ Case } & \multicolumn{2}{|c|}{ Study with EPO } & \multicolumn{2}{|c|}{ Study with PEG-EPO } \\
\hline & $\begin{array}{l}\text { EPO dose, } \\
\text { U/week }\end{array}$ & $\begin{array}{l}\text { Serum ferritin } \\
\text { before the } \\
\text { measurement } \\
\text { of hepcidin-25, } \\
\mathrm{ng} / \mathrm{ml}\end{array}$ & $\begin{array}{l}\text { PEG-EPO } \\
\text { dose, } \\
\text { U/month }\end{array}$ & $\begin{array}{l}\text { Serum ferritin } \\
\text { before the } \\
\text { measurement } \\
\text { of hepcidin-25, } \\
\mathrm{ng} / \mathrm{ml}\end{array}$ \\
\hline 1 & 2,250 & $12.1^{*}$ & 100 & $13.2^{*}$ \\
\hline 2 & 2,250 & 19.3 & 100 & $11.8^{*}$ \\
\hline 3 & 9,000 & $6.1^{*}$ & 150 & 30.8 \\
\hline 4 & 4,500 & 33.1 & 100 & $6.5^{*}$ \\
\hline 5 & 4,500 & 149.0 & 100 & 34.6 \\
\hline 6 & 4,500 & $3.8^{*}$ & 150 & $4.0^{*}$ \\
\hline 7 & 9,000 & 98.1 & 150 & $4.6^{*}$ \\
\hline 8 & 2,250 & $10.9 *$ & 100 & $11.6^{*}$ \\
\hline 9 & 9,000 & $11.6^{*}$ & 150 & 20.7 \\
\hline
\end{tabular}

* Low ferritin group.

Table 3. Effect of rhEPO on anemia and iron parameters in HD patients with low and high serum levels of ferritin

\begin{tabular}{|c|c|c|c|c|}
\hline \multirow[t]{2}{*}{ Variable } & \multicolumn{2}{|l|}{ Low ferritin group } & \multicolumn{2}{|l|}{ High ferritin group } \\
\hline & $\begin{array}{l}\text { before hepcidin-25 } \\
\text { measurement }\end{array}$ & $\begin{array}{l}6 \text { months } \\
\text { after rhEPO }\end{array}$ & $\begin{array}{l}\text { before hepcidin-25 } \\
\text { measurement }\end{array}$ & $\begin{array}{l}6 \text { months } \\
\text { after rhEPO }\end{array}$ \\
\hline $\mathrm{Hb}, \mathrm{g} / \mathrm{dl}$ & $10.6 \pm 2.6$ & $11.1 \pm 1.5$ & $11.2 \pm 0.7$ & $9.7 \pm 0.9^{*}$ \\
\hline Ferritin, ng/ml & $8.7 \pm 3.7$ & $16.8 \pm 16.5$ & $55.3 \pm 49.4$ & $29.3 \pm 21.8^{*}$ \\
\hline Transferrin, mg/dl & $276.4 \pm 25.8$ & $251.4 \pm 32.6$ & $232.0 \pm 52.5$ & $248.4 \pm 58.3$ \\
\hline
\end{tabular}

$* \mathrm{p}<0.05$ vs. data before the measurement of hepcidin-25.

Based on the baseline levels of serum ferritin before the measurement of hepcidin in two independent studies, the patients were combined and grouped into a low ferritin group (11 patients with serum ferritin levels of $<15.0 \mathrm{ng} / \mathrm{ml} ; 5$ and 6 patients in the study treated with EPO and PEG-EPO, respectively) and a high ferritin group (7 patients with serum ferritin levels of $\geq 15.0 \mathrm{ng} / \mathrm{ml} ; 4$ and 3 patients in the study with EPO and PEG-EPO, respectively) (table 2). There was no difference in gender ratio between the groups. In the low ferritin group, serum levels of hepcidin- 25 were low $(<5.0 \mathrm{ng} / \mathrm{ml})$ at all time points of the measurements after rhEPO administration (fig. 2). In contrast, they rose from the baseline of $19.8 \pm$ 12.0 to $46.8 \pm 19.8 \mathrm{ng} / \mathrm{ml}(\mathrm{p}<0.01)$ at $6 \mathrm{~h}$ and $39.3 \pm 15.5 \mathrm{ng} / \mathrm{ml}(\mathrm{p}<0.01)$ at $9 \mathrm{~h}$ after rhEPO administration in the high ferritin group.

To examine the effect of rhEPO on anemia, $\mathrm{Hb}$ and iron parameters such as ferritin and transferrin before and 6 months after the measurement of hepcidin were compared between the low and high ferritin groups (table 3). The levels of $\mathrm{Hb}$ before the measurement of hepcidin were similar between the groups. In the low ferritin group, the levels of $\mathrm{Hb}$ tended to increase from the baseline of $10.6 \pm 2.6$ to $11.1 \pm 1.5 \mathrm{~g} / \mathrm{dl}$ at 6 months after the measurement of hepcidin, although this did not reach statistical significance. In contrast, they were significantly decreased from the baseline of $11.2 \pm 0.7$ to $9.7 \pm 0.9 \mathrm{~g} / \mathrm{dl}(\mathrm{p}<0.05)$ in the high ferritin group. 


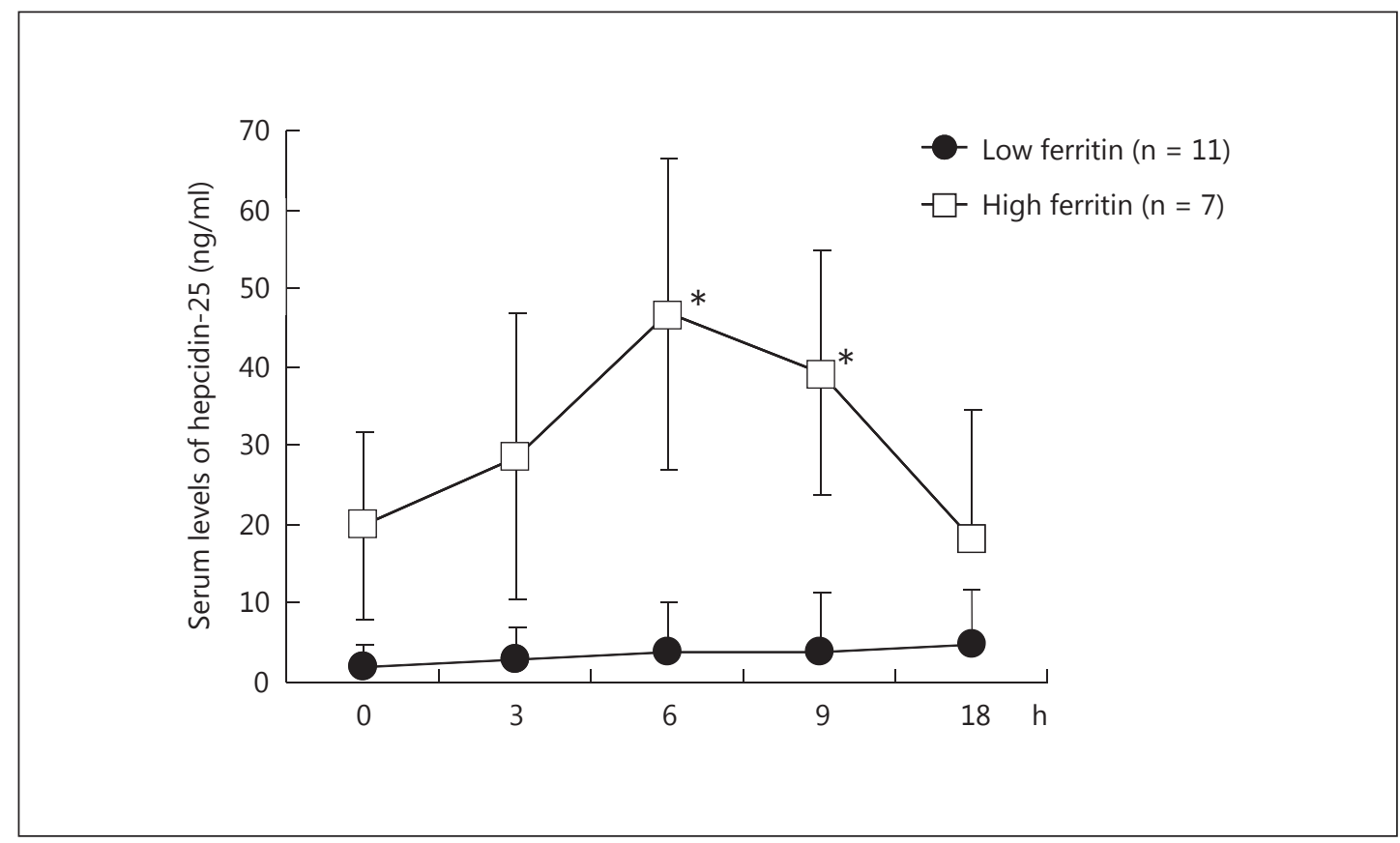

Fig. 2. Early response of serum hepcidin-25 to the intravenous administration of EPO and PEG-EPO in HD patients with low and high serum levels of ferritin. Based on the baseline of serum ferritin before the measurement of hepcidin-25 in two independent studies with either EPO or PEG-EPO, the patients were combined and grouped into a low ferritin group (11 patients with serum ferritin levels of $<15.0 \mathrm{ng} / \mathrm{ml}$; 5 and 6 patients in the study with EPO and PEG-EPO, respectively) and a high ferritin group (7 patients with serum ferritin levels of $\geq 15.0 \mathrm{ng} / \mathrm{ml} ; 4$ and 3 patients in the study with EPO and PEG-EPO, respectively). Serum levels of hepcidin-25 were low at all time points of the measurements in the low ferritin group, whereas they rose at 6 and $9 \mathrm{~h}$ after intravenous administration of rhEPO in the high ferritin group. * $\mathrm{p}<0.01,0$ vs. 6 and $9 \mathrm{~h}$.

In the low ferritin group, there was a trend toward an increase in serum levels of ferritin from the baseline of $8.7 \pm 3.7$ to $16.8 \pm 16.5 \mathrm{ng} / \mathrm{dl}(\mathrm{p}=0.06)$ at 6 months after the measurement of hepcidin, although this did not reach statistical significance. In contrast, they were significantly decreased from the baseline of $55.3 \pm 49.4$ to $29.3 \pm 21.8 \mathrm{ng} / \mathrm{dl}(\mathrm{p}<0.05)$ at 6 months after the measurement of hepcidin in the high ferritin group. However, serum levels of transferrin before and 6 months after the measurement of hepcidin were similar between the groups.

To examine the influence of inflammation on hepcidin, the values for CRP before and 6 months after the measurement of hepcidin were compared between the low and high ferritin groups. Serum levels of CRP before $(0.11 \pm 0.16$ vs. $0.04 \pm 0.04 \mathrm{mg} / \mathrm{dl}$ in the low and high ferritin groups) and 6 months after the measurement of hepcidin ( $0.08 \pm 0.07$ vs. $0.05 \pm 0.03$ $\mathrm{mg} / \mathrm{dl}$ in the low and high ferritin groups) did not differ between the groups.

\section{Discussion}

Regarding the late effect of rhEPO on hepcidin or prohepcidin in HD patients, serum levels of hepcidin have been shown to be decreased after rhEPO administration [10,11,13]. Similarly, serum prohepcidin levels were decreased after rhEPO administration and accompanied by an increase in the levels of $\mathrm{Hb}$ and hematocrit [10]. Serum levels of hepcidin were 
negatively correlated with the dose of rhEPO in HD patients, suggesting that the long-term administration of erythropoietin suppresses hepcidin levels [5].

Concerning the early effect of rhEPO on hepcidin, several studies using healthy volunteers have shown an early rise in hepcidin $[14,15]$ followed by its suppression within 2-3 days after rhEPO administration $[15,16]$. Our study showed a similar pattern, since the shortand long-acting rhEPO induced an early and significant rise in serum hepcidin-25 in HD patients. However, the time to reach the maximum levels of hepcidin and return to the baseline after rhEPO was longer than in healthy volunteers [14] probably because of the reduced clearance of hepcidin and rhEPO in HD patients [21]. In our series, an increase in serum hepcidin-25 in response to rhEPO appears to be dependent on ferritin but not on gender or circadian rhythm $[5,20]$. In a state of low ferritin, indicative of iron deletion, low hepcidin facilitates iron availability for erythropoiesis by increasing iron absorption and efflux $[1,2]$. In support of our finding, poor response of hepcidin to rhEPO has been associated with HD patients with low serum ferritin [22]. A recent in vitro study has shown that a low dose of rhEPO increases the hepcidin expression, whereas a high dose of rhEPO suppresses the hepcidin expression in human hepatocytes, depending on the activation of the C/EBP $\alpha$ pathway [23]. In addition, an in vivo study has shown that ferritin upregulates the expression of hepcidin in mice [24]. Our data, together with previous data, suggest that, in HD patients, the rhEPO-induced early rise in hepcidin- 25 may be dependent on ferritin levels and/or other pathways.

On the contrary, our study showed that serum levels of hepcidin-25 were significantly decreased on days 5-7 after PEG-EPO administration compared to the baseline, suggesting that as the late effect, rhEPO suppresses hepcidin in HD patients, which is similar in healthy volunteers $[15,16]$. Although the precise mechanisms are unknown, the rhEPO-induced suppression of hepcidin at a late phase may be mediated by circulating factors or signals derived from bone marrow cells $[15,25,26]$ and indirect mechanisms affecting the hematopoietic activity in bone marrow cells [27].

It remains inconclusive whether an alteration of serum hepcidin-25 and ferritin is predictive of the response to rhEPO in HD patients. For example, no difference was found in the serum levels of prohepcidin and hepcidin between HD patients hyporesponsive and responsive to rhEPO $[12,28,29]$. Serum hepcidin was correlated positively with ferritin $[5$, 29] and negatively with the dose of rhEPO [5], but failed to predict the response to rhEPO. However, lower serum levels of hepcidin [30] and ferritin [21,31] have been associated with increased resistance to rhEPO in HD patients. In contrast, our study showed a trend toward an increase of $\mathrm{Hb}$ after rhEPO in HD patients with low serum levels of hepcidin-25 and ferritin. Furthermore, it was found that the levels of $\mathrm{Hb}$ were significantly decreased in those with high serum levels of hepcidin-25 and ferritin. These data suggest that an alteration of serum levels of hepcidin-25 and ferritin may be predictive of the response to rhEPO in HD patients. In support of our finding, serum levels of hepcidin or prohepcidin after rhEPO administration were negatively correlated with $\mathrm{Hb}$ in HD patients [10]. Low serum levels of prohepcidin have been associated with a lower dose requirement of rhEPO in HD patients [32]. In addition, increased serum levels of hepcidin or prohepcidin have been associated with rhEPO-resistant HD patients $[12,26]$. Our data, together with these previous data, suggest that an alteration of serum levels of hepcidin- 25 and ferritin may be predictive of the response to rhEPO in HD patients. Inflammation increases serum levels of ferritin and hepcidin in HD patients $[1,2,8]$, which is related to a hyporesponsiveness to rhEPO [28]. Since our patients had normal serum levels of CRP and IL-6, absence of inflammation may be crucial for a better response to rhEPO in HD patients.

In summary, our study showed that in HD patients, the short- and long-acting rhEPOs exert similar biphasic effects on hepcidin-25 in early upregulation followed by late down- 
Takasawa et al.: Regulation of Hepcidin-25 by Short- and Long-Acting rhEPO May Be

regulation. An early rise in serum hepcidin-25 in response to rhEPO may be dependent on serum ferritin and predictive of the response to rhEPO in HD patients. Further studies using larger numbers of HD patients are necessary to confirm this finding.

\section{Acknowledgements}

This study has been supported by The Kidney Foundation, Japan (JKFB09-55).

\section{Disclosure Statement}

The authors have no conflicts of interest to disclose.

\section{References}

1 Hentze MW, Muckenthaler MU, Galy B, Camaschella C: Two to tango: regulation of mammalian iron metabolism. Cell 2010;142:24-38.

- Ganz T: Hepcidin and iron regulation, 10 years later. Blood 2011;117:4425-4433.

-3 Tomosugi N, Kawabata H, Wakatabe R, Higuchi M, Yamaya H, Umehara H, Ishikawa I: Detection of serum hepcidin in renal failure and inflammation by using ProteinChip System. Blood 2006;108:1381-1387.

4 Małyszko J, Małyszko JS, Hryszko T, Pawlak K, Mysliwiec M: Is hepcidin a link between anemia, inflammation and liver function in hemodialyzed patients? Am J Nephrol 2005;25:586-590.

5 Ashby DR, Gale DP, Busbridge M, Murphy KG, Duncan ND, Cairns TD, Taube DH, Bloom SR, Tam FW, Chapman RS, Maxwell PH, Choi P: Plasma hepcidin levels are elevated but responsive to erythropoietin therapy in renal disease. Kidney Int 2009;75:976-981.

-6 Valenti L, Girelli D, Valenti GF, Castagna A, Como G, Campostrini N, Rametta R, Dongiovanni P, Messa P, Fargion S: HFE mutations modulate the effect of iron on serum hepcidin-25 in chronic hemodialysis patients. Clin J Am Soc Nephrol 2009;4:1331-1337.

-7 Eleftheriadis T, Kartsios C, Liakopoulos V, Antonioadi G, Dista M, Papadopoulos C, Anifandis G, Skirta A, Markala D, Stefanidis I: Does hepcidin affect erythropoiesis in hemodialysis patients? Acta Haematol 2006; 116:238-244.

-8 Kuragano T, Shimonaka Y, Kida A, Furuta M, Nanami M, Otaki Y, Hasuike Y, Nonoguchi H, Nakanishi T: Determinants of hepcidin in patients on maintenance hemodialysis: role of inflammation. Am J Nephrol 2010;31: 534-540.

9 Malyszko J, Malyszko JS, Mysliwiec M: Serum prohepcidin and hepcidin in hemodialyzed patients undergoing iron therapy. Kidney Blood Press Res 2009;32:235-238.

10 Arabul M, Gullulu M, Yilmaz Y, Eren MA, Baran B, Gul CB, Kocamaz G, Dilek K: Influence of erythropoietin therapy on serum prohepcidin levels in dialysis patients. Med Sci Monit 2009;15:CR583-CR587.

11 Weiss G, Theurl I, Eder S, Koppelstaetter C, Kurz K, Sonnweber T, Kobold U, Mayer G: Serum hepcidin concentration in chronic haemodialysis patients: associations and effects of dialysis, iron and erythropoietin therapy. Eur J Clin Invest 2009;39:883-890.

12 Shinzato T, Abe K, Furusu A, Harada T, Shinzato K, Miyazaki M, Kohno S: Serum pro-hepcidin level and iron homeostasis in Japanese dialysis patients with erythropoietin (EPO)-resistant anemia. Med Sci Monit 2008; 14:CR431-CR437.

13 Shoji S, Inaba M, Tomosugi N, Okuno S, Ichii M, Yamakawa T, Kurihara S: Greater potency of darbepoetin- $\alpha$ than erythropoietin in suppression of serum hepcidin-25 and utilization of iron for erythropoiesis in hemodialysis patients. Eur J Haematol 2013;90:237-244.

14 Lainé F, Laviolle B, Ropert M, Bouguen G, Morcet J, Hamon C, Massart C, Westermann M, Deugnier Y, Loréal O: Early effects of erythropoietin on serum hepcidin and serum iron bioavailability in healthy volunteers. Eur J Appl Physiol 2012;112:1391-1397.

15 Ashby DR, Gale DP, Busbridge M, Murphy KG, Duncan ND, Cairns TD, Taube DH, Bloom SR, Tam FW, Chapman R, Maxwell PH, Choi P: Erythropoietin administration in humans causes a marked and prolonged reduction in circulating hepcidin. Haematologica 2010;95:505-508.

16 Robach P, Recalcati S, Girelli D, Campostrini N, Kempf T, Wollert KC, Corbella M, Santambrogio P, Perbellini L, Brasse-Lagnel C, Christensen B, Moutereau S, Lundby C, Cairo G: Serum hepcidin levels and muscle iron proteins in humans injected with low- or high-dose erythropoietin. Eur J Haematol 2013;91:74-84. 
Takasawa et al.: Regulation of Hepcidin-25 by Short- and Long-Acting rhEPO May Be Dependent on Ferritin and Predict the Response to rhEPO in Hemodialysis Patients

17 Peters HP, Rumjon A, Bansal SS, Laarakkers CM, van den Brand JA, Sarafidis P, Musto R, Malyszko J, Swinkels DW, Wetzels JF, Macdougall IC: Intra-individual variability of serum hepcidin-25 in haemodialysis patients using mass spectrometry and ELISA. Nephrol Dial Transplant 2012;27:3923-3929.

-18 Ford BA, Eby CS, Scott MG, Coyne DW: Intra-individual variability in serum hepcidin precludes its use as a marker of iron status in hemodialysis patients. Kidney Int 2010;78:769-773.

19 Ferrari M, Mistura L, Patterson E, Sjöström M, Díaz LE, Stehle P, Gonzalez-Gross M, Kersting M, Widhalm K, Molnár D, Gottrand F, De Henauw S, Manios Y, Kafatos A, Moreno LA, Leclercq C; HELENA study group: Evaluation of iron status in European adolescents through biochemical iron indicators: the HELENA Study. Eur J Clin Nutr 2011;65:340-349.

20 Itkonen 0, Parkkinen J, Stenman UH, Hämäläinen E: Preanalytical factors and reference intervals for serum hepcidin LC-MS/MS method. Clin Chim Acta 2012;413:696-701.

21 Jensen JD, Madsen JK, Jensen LW, Pedersen EB: Reduced production, absorption, and elimination of erythropoietin in uremia compared with healthy volunteers. J Am Soc Nephrol 1994;5:177-185.

-22 Kalantar-Zadeh K, Lee GH, Miller JE, Streja E, Jing J, Robertson JA, Kovesdy CP: Predictors of hyporesponsiveness to erythropoiesis-stimulating agents in hemodialysis patients. Am J Kidney Dis 2009;53:823-834.

-23 Pinto JP, Ribeiro S, Pontes H, Thowfeequ S, Tosh D, Carvalho F, Porto G: Erythropoietin mediates hepcidin expression in hepatocytes through EPOR signaling and regulation of C/EBP $\alpha$. Blood 2008;111:5727-5733.

-24 Feng Q, Migas MC, Waheed A, Britton RS, Fleming RE: Ferritin upregulates hepatic expression of bone morphogenetic protein 6 and hepcidin in mice. Am J Physiol Gastrointest Liver Physiol 2012;302:G1397-G1404.

25 Pak M, Lopez MA, Gabayan V, Ganz T, Rivera S: Suppression of hepcidin during anemia requires erythropoietic activity. Blood 2006;108:3730-3735.

26 Vokurka M, Krijt J, Šulc K, Nečas E: Hepcidin mRNA levels in mouse liver respond to inhibition of erythropoiesis. Physiol Res 2006;55:667-674.

27 Sasaki Y, Noguchi-Sasaki M, Yasuno H, Yorozu K, Shimonaka Y: Erythropoietin stimulation decreases hepcidin expression through hematopoietic activity on bone marrow cells in mice. Int J Hematol 2012;96:692-700.

28 Malyszko J, Malyszko JS, Mysliwiec M: Hyporesponsiveness to erythropoietin therapy in hemodialyzed patients: potential role of prohepcidin, hepcidin, and inflammation. Ren Fail 2009;31:544-548.

29 Kato A, Tsuji T, Luo J, Sakao Y, Yasuda H, Hishida A: Association of prohepcidin and hepcidin-25 with erythropoietin response and ferritin in hemodialysis patients. Am J Nephrol 2008;28:115-121.

-30 Brătescu LO, Bârsan L, Munteanu D, Stancu S, Mircescu G: Is hepcidin-25 a clinically relevant parameter for the iron status in hemodialysis patients? J Ren Nutr 2010;20(5 Suppl):S77-S83.

31 Gaweda AE, Goldsmith LJ, Brier ME, Aronoff GR: Iron, inflammation, dialysis adequacy, nutritional status, and hyperparathyroidism modify erythropoietic response. Clin J Am Soc Nephrol 2010;5:576-581.

-32 Caliskan Y, Yelken B, Ozkok A, Gorgulu N, Yazici H, Telci A, Yildiz A: Lower serum prohepcidin levels associated with lower iron and erythropoietin requirements in hemodialysis patients with chronic hepatitis C. BMC Nephrol 2012;13:56. 